\title{
IMPACT OF FISHERY ASSOCIATION MANAGEMENT ON FISHERY COMMUNITY
}

Case study in Vinh Giang Commune, Phu Loc District, Thua Thien Hue Province, Vietnam

\section{Nguyen Van Chung}

MSc. student of Faculty of Economics and Social Sciences, Szent István University, Hungary E-mail: vanchunghuaf@gmail.com

\begin{abstract}
Tam Giang lagoon system has got an area size of around $22.100 \mathrm{ha}$; a length of $68 \mathrm{~km}$ along the coast of central Vietnam. In which, the animal system is abundant, including many kinds of shrimp, fish and crab. Vinh Giang is a commune which belongs to the Tam Giang lagoon system. It is a place, where fishing activities started long time ago and developed strong fishery culture. There are many fishery groups who use this resource, including fixed gears fishing, mobile gears fishing and aquaculture. The numbers of fishers are increasing; meanwhile the resource under harvest is limited. Accordingly, conflict becomes common among household groups in aquatic resource exploitation and use. They use many methods to increase their efficiency, like event destructive fishing. This situation led to overexploitation and depletes resources. The local government tries to take some measures in resource management, but the effectiveness was not significant. Specially, they give emphasis for administrative management mechanism and coercion to reduce approach level, exploit resource in general and fisheries management in particular. The centralized management mechanism didn't seem suitable in common pool resource (Tuyen, 2008). Thus, the most important is to renew management system in aquaculture, fishing and other resource in lagoon. The fisheries management system improverment is implemented comprehensive in fishing technology, fishing method and management regulations in order to reach a goal that is not harmful to environment and biodiversity in aquatic resource. Although, the Local Government and other organizations coordinated management in aquculture and fishery is there, the connection has not been close enough to bring a change. The fishing and aquculture area planning were not suitable and clearly. In addition, whereas, government organization, local government weren't enough official, time, expenditure and resource to remain management activities on large area. Fisher has not participated actively in in the protection of aquatic resource in the community yet. Because of this, the overexploitation continuied growing from time to time. These reasons affect aquatic resource and fisher's livelihood.
\end{abstract}

To solve this problem, the community has to clear property right regime to reinforce aquatic resource management capacity (Tuyen, 2010). Therefore, the fishery management model base on community was establishment in many communes. In which, fishery association is subject of the model. Moreover, Vinh Giang commune, that the first commune is right allocated in water surface resource management, exploitation and using. The nature of the community based fisheries management model is decentralized in participation of fisher and local government. Fishery association is social-professional organization. The participation of fisher in the association is voluntary; they participate in activities such as: fishing, aquaculture, consuming, processing and logistic services fisheries. Fishery association establishment created the change in aquatic resource management. In which, it included the change in the number of fisher, area, fishing equipment, yield, income and fisher's awareness. 
From this research, it will show the advantages and disadvantages in aquatic resource management process, the changes and improvements in the livelihood of fisher through support by fishery association.

Keywords: fishery association, resource management, fishery

\section{Introduction}

In current years, fisheries industry in Vietnam created significant result; to contributed jobs for labor force and improved living standard of fisher. Moreover, it brought high status for Vietnam on the world market in export aspect (Hoa, 2009). But in the overall, fisheries industry has had problems in planning, overexploitation and environment pollution. In which, many species which have high economic value and rare but they are having endangered and fisher's livelihood is impacted.

Tam Giang lagoon system has area around 22.100 ha over a length of $68 \mathrm{~km}$ along the coast of central Vietnam. It is the largest lagoon of Southeast Asia with resource diversity. In which, the animal system is abundant including 230 fish species, 46 benthos species, 66 zooplankton species, 31 high aquatic plants species, 18 aquatic grasses species, 100 algae species, 221 planktonic species (Phuoc, 2012). This is advantage condition to develop fishery in communities which belong to the Tam Giang lagoon. Tam Giang lagoon became the main resource which contributed to create jobs and increase income for the inhabitants.

Thua Thien Hue is a province which belongs to Central Vietnam. It has a long beach and large Tam Giang lagoon. In which, water surface area on lagoon occupies $48.2 \%$ total area of Tam Giang lagoon. Moreover, the Tam Giang lagoon was a main livelihood of populations in 33 communes. They made up 1/3 total population in Thua Thien Hue province. With advantage features in fishery resource, lagoon became direct and indirect factor in the livelihood of 300.00 fishers, their life based on lagoon (Phuoc, 2012).

Tam Giang lagoon is common pool resource that is open and accessable for anyone. Therefore, the community exploits the available resource with increasing number of fisher and equipments. From this situation, the fishers always compete together to get the highest profit. This is reason leading to conflict among household groups in aquatic resource exploiting and using. They used many methods to get higher efficiency, event exterminate fishing. This situation led to overexploitation and depletes resources (Tam, 2010). Thus, under supported by Common Pool Resource Management in Central Vietnam project, the fishery association was established at many communes. By specific activities, Fishery Association created active change and improvement in aquatic resource management and improved living standard of fisher. This research contributes to demonstrate clearly about these changes. In this article, it is focused on the change in fisher's income and the improvements of community under implementation by fishery association in Vinh Giang commune.

\section{Research content and methodology}

The research content concentrates to fishery association establishment process such as: The reasons are to establish fishery association; the participation of fisher; the activity co-ordination is among fishery association, province fishery association and Local Government. 
The main content focuses on fishery association activities and its efficiency, including propagandize information, patrol and protect natural resources, solve conflicts, arrange fishing equipment, establish breeding ground and seaweed habitat area, open waterway. Specially, evaluate the change in resource and variance on household income in the fishery.

\section{Collect secondary information}

Secondary information is collected through available data which includes reports in the research location such as: socioeconomic reports of the Vinh Giang commune; reports about fishing and aquaculture activities at the Vinh Giang commune and Phu Loc District; reports of Giang Xuan fishery association and province fishery association in Thua Thien Hue province in the period from 2007 to 2012.

\section{Collect primary information}

In-depth interview: interview 10 members (2 members are official in local government; 3 members are official of fishery association and 5 members have rich experience in fisher community). Specific, chairman and vice chairman of fishery association, official managers fishery at community. Information collection includes history, structure, organization and operation in model; really situation fishery association development, planning; the role, task and regulation of association; the change in fishing and aquaculture activities including the number of household, equipment, species, yield, income;

Group discussion: to organize 3 times group discussion. The first one, it includes fisher in aquaculture group, the second one is fisher in fishing group and the third one is fisher between fishing and aquaculture group. Each group has 5-7 members in the community.

Content of group discussion: retest information from in-deep interview; to collect information at the community level; implementation and development process of fishery association (using timeline); fishery association role; changing of aquatic resource and livelihood; awareness of household in co-management.

Household interview: 60 households are selected randomly (stratified sampling) for interview based on two criterion. These include the member of fishery association and the participant in fishing or aquaculture. This tool is conducted through the questionnaire to get information about the situation of each household, the general information about household; income generating activities; the change in income; household's awareness about community based fishery management; the participation of household in association activities; general information about fishing and aquaculture activities including change in species, area, scale, equipment; fishing time; yield; the opinion and suggestion of household for model development process.

Observation method: This tool is used while the whole process of this research was undergoing. The major aim of this tool is to observe the general environment of villages, daily life and the fishing and aquaculture activities. 


\section{The results and discussion}

\section{Fishing trend and associated problems in the community}

Lagoon area in Ving Giang has 1.260 ha, over 300 households inside and outside of the commune who involves lagoon with many fishing methods such as the fixed gear fishing (i.e. Stake trap and bottom nets); mobile gears fishing (i.e grid net and Chinese Lu); and aquaculture. The number of fishing increased quickly; it created pressure on the lagoon. With conception "land is private property and fishery ground is common property", the fisher didn't care about sustainable development of aquatic resource. They tried to find the best way to exploit over resource on the lagoon. Many types of equipment have been becoming destructively which appeared on the lagoon. Chinese Lu (bottom trap) appeared 7 years ago but it developed quickly, the number of equipment was high, the mesh was small. Besides, some types of equipment used electricity; it was becoming destructive higher than other types of equipment. Ving Giang Commune People Committee tried to implement their responsibility in fishery management and aquatic resources protection. They were not only ineffective in the management but also arose many complex problems. Firstly, local government wasn't enough official, time, expenditure, resource to remain management activities on large area. Secondly, fisher hasn't participated actively in protection aquatic resource in the community yet. Thus, the resource on the lagoon in Ving Giang has been exhausted. These problems were illustrated specific during fisheries development process in Vinh Giang commune.

Before 1975: Stake trap households had to bide stake trap location through "Van" (fishing village). In 1975-1985, fishery was managed by team 10 which belonged to Giang Dong cooperative. This management method was increasing management cost and production cost of household who participated in bidding. Thus, fisher did not feel secure to invest on the production. In 1985-1993: Commune coordinated to District departerment of fishery to establish stake trap group and fisheries production which supported to manage fishing households in group. To implement seawead delimiting and only pay working day money for participatory household in production. In stake trap case, the location was selected randomly but District got fee and devided 15\% for stake trap group. In this time, group managed many activities but management cost was low; the rate between charge and profit wasn't clearly between levels which led to disintegrate stake trap group

In 1994-2007: Fisheries management activity from aquaculture to fishing was delivered to Nghi Xuan village and Commune People Committee. Giang Dong fishery cooperative and Cooperative could get $50 \%$ fees from activities such as grid-net, seawead, stake trap. Management function about productive activities was mainly which led to fishers became proactively in production based on their capacity. However, this management method has been getting difficultly; water surface area is large while manager staff had only village heads, commune's police and two team leader of productive group. These were reason leading to efficiency management was still low. In addition, source of community was limitation. Hence, general tendency is based on fisher. They participate in fisheries management. Community based management is method that shares responsibility and interests to increase fisher and community role in aquaculture and fishing management in Ving Giang lagoon. 
In 2008, Phu Loc District People Committee was empowered by Thua Thien Hue Provincal People Committee and consulted by Faculty of Extension and Rural Development in Hue University of Agriculture and Forestry to establish community based fishery management model. To implement this model, the neccessary is to establish fishery association; they will participate in fisheries management process in community. After Giang Xuan association was established in 2008; until now, it included 125 members that were divided 3 sub-associations such as: mobile gears fishing sub-association, fixed gears fishing sub-association and aquaculture sub-association. It creates an improvement in management and development in the fishery. Fishery association is social- professional organization. The members are volunteers; they participate in activities such as: fishing, aquaculture, consuming, processing and logistic services fisheries. The aim establishes association: collection of individuals working in the field of fisheries production in the area, to unite to support each other in the production and development of aquatic resources, environmental protection and the legitimate interests of its members. With efficiently activities, association mobilized community's participation in management and development fisheries.

\section{The change in fishing and aquaculture}

In aquaculture group case in Vinh Giang commune, aquaculture activity is main income source. It impacts large on their livelihood. In the past, they always focused on shrimp specialized farming because shrimp price and yield had high. So, fisher could get high profit in a short time. However, shrimp is disease susceptible and mass-death occurs when water environment is polluted by some sort of biological or chemical pollutants. Thus, households had lost when shrimp had mass-death. This was a reason leading to many households became more and more poor. After that, the Department of Aquatic Resource Protection and experts supported new technology in aquaculture for fisher through the management of fishery association. They replaced shrimp specialized farming by variety farming. The impact of association created advantage for the change in fishery development process in Vinh Giang commune. The main results are shown in the table 1.

Table 1: The change in aquaculture, Vinh Giang commune

\begin{tabular}{|c|c|c|c|c|c|c|c|}
\hline \multirow[t]{2}{*}{ Criteria } & \multirow[t]{2}{*}{ Unit } & \multicolumn{2}{|c|}{$\begin{array}{c}\text { Before the } \\
\text { establishment } \\
\text { of associations }\end{array}$} & \multicolumn{4}{|c|}{$\begin{array}{l}\text { After the establishment of } \\
\text { associations }\end{array}$} \\
\hline & & 2007 & 2008 & 2009 & 2010 & 2011 & 2012 \\
\hline Variety farming area & $\mathrm{Ha}$ & 30 & 108.3 & 117.5 & 184.7 & 200.7 & 200.7 \\
\hline $\begin{array}{l}\text { Shrimp specialized farming } \\
\text { area }\end{array}$ & $\mathrm{Ha}$ & 96.5 & 18.2 & 13 & 13 & 10 & 9 \\
\hline $\begin{array}{l}\text { The number of variety } \\
\text { farming households }\end{array}$ & $\mathrm{HH}$ & 0 & 40 & 98 & 200 & 255 & 255 \\
\hline $\begin{array}{l}\text { The number of shrimp } \\
\text { specialized } \\
\text { households }\end{array}$ & $\mathrm{HH}$ & 191 & 186 & 122 & 26 & 5 & 4 \\
\hline $\begin{array}{l}\text { Average income per variety } \\
\text { farming households }\end{array}$ & $\begin{array}{l}\text { Mil.do } \\
\text { ng }\end{array}$ & 16.7 & 18.34 & 20.37 & 19.84 & 27.82 & 29.42 \\
\hline $\begin{array}{l}\text { Average income per shrimp } \\
\text { specialized } \\
\text { households }\end{array}$ & $\begin{array}{l}\text { Mil.do } \\
\text { ng }\end{array}$ & 90.67 & 18.24 & 16.56 & 16.07 & 18.9 & 19.05 \\
\hline
\end{tabular}

"Source: Statistic reports of commune, 2007-2012 and household interview, 2013” (HH: household) 
From table 1, it is easy to observe that, there are some significant changes in aquaculture area following the two trends in the commune. The first one, increase variety farming area and the second one, decrease shrimp specialized farming area. In 2007, variety farming area was 30 hectare. But, in 2008, this area increased quickly up to 108.3 hectare. It continued to increase from 117.5 hectare in 2009 to 200.7 hectare in 2012. In the other hand, shrimp specialized farming area declined from 96.5 hectare in 2007 to 9 hectare in 2012. The change in aquaculture area led to the change in the number of household. The main reasons for the increase of variety farming area are; fisher was loose when applied shrimp specialized farming; variety farming had high efficiency and sustainability, moreover it contributed to reduce risks. Besides the change in the area, the fisher's income increased steady in two forms. It contributed to improve fisher livelihood.

As far as the household income concerned, fishing activity plays the major role. Thus, it has crucial role in fisheries sustainable development process. The reduction or elimination destructive fishing equipments become urgency in current context. The role of fishery association becomes more and more important in aquatic resource management process. Fishing activities were monitored and managed by the association through fishing regulations which established by all members of association and local government. Thus, it contributed to create stability and sustainability in the income of the household. The result was shown in table below

Table 2: The change in income of household(Mil.dong/HH)

\begin{tabular}{|l|c|c|c|c|c|c|}
\hline \multirow{2}{*}{$\begin{array}{c}\text { Type of } \\
\text { equipment }\end{array}$} & \multicolumn{4}{|c|}{$\begin{array}{c}\text { Before the } \\
\text { establishment of } \\
\text { associations }\end{array}$} & \multicolumn{4}{|c|}{ After the establishment of associations } \\
\cline { 2 - 7 } & $\mathbf{2 0 0 7}$ & $\mathbf{2 0 0 8}$ & $\mathbf{2 0 0 9}$ & $\mathbf{2 0 1 0}$ & $\mathbf{2 0 1 1}$ & $\mathbf{2 0 1 2}$ \\
\hline Stake trap & 24.48 & 26.31 & 32.99 & 35.29 & 33.56 & 38.7 \\
\hline Bottom traps & 23.37 & 23.79 & 28.33 & 37.77 & 33.82 & 30.23 \\
\hline Gill-net & 10.42 & 6.1 & 8.78 & 9.46 & 10.52 & 9.75 \\
\hline Fish-pens & - & 5.4 & 10.5 & 12.86 & 14.09 & 14.3 \\
\hline
\end{tabular}

"Source: household interview, 2013"

Table 2 illustrated that fishing activities created high income for fisher. The income increased significantly after establishment association. Especially, in the stake trap industry, the income went up quickly from 24, 48 mil dong in 2007 to 38.7 mil dong in 2012. In this case was explained that fishery association implemented planning to arrange stake trap and open waterway. This was reason leading to increase yield of shrimp and fish in recent years. On the other hand, there was advantage change in fishing activities. Fishery association encouraged fisher to develop fish-pen industry. It started to implement in 2008 and the income was 5,4 mil dong. It still increased in the next years and was 14.3 mil dong in 2012. From this case, we can see that the association contributed to adjust in fishing activities for increasing the income of fisher. One more thing, fishery association wanted to replace or reduce destructive fishing activities by fish-pen because fish-pen was known as environmental friendly fishing activity. In bottom trap and grid-net activities case, their income had a fluctuation from 2007 to 2012 . In overall, it had increased slightness for 5 years. 
The improvement and participation in community.

\section{The participation of community}

From 2008 until now, association increased to control destructive fishing activities, arrange stake trap, control number of equipment and reduce specialize shrimp feed which led to environmental resource became more advantages. Specific fishing sub-zones planning, breeding grounds, spawning grounds, seaweed protection and waterway opening are good conditions to develop animal system. To implement all these things, the participation of household had important role to decide the success of activities

More importantly, many research shown that the participation of the fisher is the main element to advance efficiency in community activities. Similarly, in Ving Giang, the fisher participated in activities with high rate. The rate of participation is described in table 3 .

Table 3: The participation of community in resource management activities

\begin{tabular}{|l|c|c|}
\hline \multicolumn{1}{|c|}{ Activities } & $\begin{array}{c}\text { Participatory } \\
\text { household } \\
(\mathbf{N = 6 0 )}\end{array}$ & $\begin{array}{c}\text { Rate } \\
(\mathbf{\%})\end{array}$ \\
\hline Community consultation meeting & 54 & 90 \\
\hline Participate in choosing and voting management board & 60 & 100 \\
\hline Participate people meeting to build plan annual actions & 60 & 100 \\
\hline Discussion, suggestion to build regulation and collective action & 54 & 90 \\
\hline Monitor and observer association's activities & 36 & 60 \\
\hline Participate periodic activities & 60 & 100 \\
\hline
\end{tabular}

"Source: household interview, 2013"

After 6 years establishment fishery association, fisher understood benefits when they participated in the association. They accepted and implemented activities of the association. It is shown in the rate of participatory member which were higher than $90 \%$ in activities. In which, only $60 \%$ member participated monitoring and built collective actions. This case illustrated the members were still passively in monitoring.

\section{Evaluation of management improvements}

Moreover, the establishment fishery association was a step breaking through in management. It contributed to advance solidarity of fisher in community. With bottom-up approach, Giang Xuan association got success in management improvements. These improvements were evaluated by members in the association. A group discussion was organized through participation of Excutive Broad of fishery association and representative of associate in each sub-association. Participatory rural appraisal method was applied to find consensus in criterion which was prepared before. Evaluation criterion shown management improvement situation compared with wishes in the future. \% concensus of evaluation result shows that workload was implemented until now. \% remaining need to implement in the future. Evaluation result was shown in table 4 and 5. 
Table 4: The management improvements of model

\begin{tabular}{|c|c|c|}
\hline Criteria & Description & $\begin{array}{c}\text { Situation } \\
\text { compares with } \\
\text { desire }(\%)\end{array}$ \\
\hline Self-management association & Self-organization operating activities of FAs, to solve the problems in the community & 70 \\
\hline $\begin{array}{l}\text { The boundary demarcation of water } \\
\text { surface is more clear }\end{array}$ & $\begin{array}{l}\text { Members in association knows the boundary demarcation of water surface of the } \\
\text { commune, management zones of association, the exploiting sub-zones, conservation } \\
\text { area and breeding ground }\end{array}$ & 80 \\
\hline To divide reasonable fishing sub-zones & Based on experience and knowledge of community to divide sub-zones & 100 \\
\hline $\begin{array}{l}\text { Number of fishing household, the } \\
\text { number of equipment in sub-zones }\end{array}$ & $\begin{array}{l}\text { The sub-zones have regulations to control the number of fishing household and } \\
\text { equipment. }\end{array}$ & 50 \\
\hline $\begin{array}{l}\text { Partition in the conservation sub-zone } \\
\text { and resource recovery sub-zone }\end{array}$ & $\begin{array}{l}\text { The conservation sub-zone and breeding ground have regulations at the time. It doesn't } \\
\text { allow exploiting. }\end{array}$ & 100 \\
\hline $\begin{array}{l}\text { Setting regulations and pre-conditions } \\
\text { for participation in fishing }\end{array}$ & $\begin{array}{l}\text { Fishing households must register vocation with the association and the number of } \\
\text { equipment and pay fee. }\end{array}$ & 100 \\
\hline $\begin{array}{l}\text { Reasonable regulation for mesh } \\
\text { equipment }\end{array}$ & $\begin{array}{l}\text { Dimension of stake trap, bottom trap according to regulation is } 2 \mathrm{a}=18 \mathrm{~mm} \text {. Without any } \\
\text { households violation }\end{array}$ & 0 \\
\hline $\begin{array}{l}\text { Appropriate regulations for resource } \\
\text { protection patrols and handling } \\
\text { violations }\end{array}$ & Monthly, association conduct periodic patrols to check for irregular situation of the rules. & 75 \\
\hline $\begin{array}{l}\text { The forbidden destructive fishing } \\
\text { activities became efficient }\end{array}$ & $\begin{array}{l}\text { Without fisher implements destructive fishing on the lagoon where belongs to } \\
\text { management of the association. }\end{array}$ & 80 \\
\hline Breeding grounds were protected better & There wasn't fishing activities on the breeding ground during the time spans of fish & 75 \\
\hline Aquatic animal disease reduction & Aquatic animal diseases have decreased since the animal forms interspersed. & 80 \\
\hline The result of fishery is improving & Increases profitable household, decrease loss household & 80 \\
\hline
\end{tabular}

(Source: Group discussion, 2013) 
Table 5: Awareness of community about management improvement

\begin{tabular}{|l|c|l|}
\hline \multicolumn{1}{|c|}{$\begin{array}{c}\text { Management } \\
\text { improvement }\end{array}$} & $\begin{array}{c}\text { Implementation } \\
\text { Year }\end{array}$ & \multicolumn{1}{|c|}{ Result from community awareness } \\
\hline $\begin{array}{l}\text { Establish and develop } \\
\text { association }\end{array}$ & 2008 & $\begin{array}{l}\text { - To protect productive right; allocated fishing } \\
\text { right }\end{array}$ \\
\hline $\begin{array}{l}\text { Fishing sub-zones } \\
\text { specific planning } \\
\text { establishment }\end{array}$ & 2008 & $\begin{array}{l}\text { - More advantage production; conflicts } \\
\text { reduction. } \\
- \text { It had specific regulations in participatory } \\
\text { condition in fishing } \\
- \text { Yield of fishing and aquaculture increased } \\
\text { higher than before 2008 }\end{array}$ \\
\hline $\begin{array}{l}\text { Association applied } \\
\text { management } \\
\text { regulations }\end{array}$ & $2008-2013$ & $\begin{array}{l}\text { - Fisher knew which activities allow } \\
\text { implementation or which activities forbidden } \\
\text { on lagoon } \\
- \text { To protect benefit in production and reduce } \\
\text { destructive fishing }\end{array}$ \\
\hline $\begin{array}{l}\text { Implement } \\
\text { empowerment in } \\
\text { fishing }\end{array}$ & 2009 & \begin{tabular}{l} 
- Fisher knew who are master on lagoon \\
\hline $\begin{array}{l}\text { Increase patrol and } \\
\text { protection }\end{array}$
\end{tabular} $2008-2013$ \\
\hline
\end{tabular}

Source: Household interview, 2013

\section{Conclusion}

The research illustrated that the community had an important role in fishing and aquaculture. It has built consensus among the community and local governments in aquaculture and fishing.The active participation of the community in the process of decision making, planning and implementation of the regulations have important implications in the management of local fisheries.Moreover, active fishery association in all activities, from planning to operations in deployment activities of associations. The Fishery Association Executive Committee has conducted a review and statistical and registration organizations fishing activities, as well as the full charge

Once more thing, fishery association contributed to create diversity livelihood for fisher in Vinh Giang community through new forms in fishing and aquaculture such as fish-pen and variety farming. It is condition to improve yield of fishery, water environment and sustainable fishery development. These were demonstrated through the change in productivity of fish and shrimp and fisher's income. In general, after establishment association, income of household increased significantly. Specially, stake trap income raise up 5.71 mil dong from 2009 to 2012 and 3.8 mil dong was fish-pen income from 2009 to 2012. Moreover, many fishers transfered aquaculture form from shrimp specialized farming to variety farming and they got success. Income from variety farming has increased 9.05 mil dong for 4 years. Also, income from variety farming is lower than income from Shrimp specialized farming but it has less rick which is necessary element to improve sustainable livelihood of fisher in the future. 
Fisher determined their subject role in aquatic resource management. They accepted and implemented good regulations in resource fishing and use such as fishing sub-zones specific planning; Patrol, protection activity and destructive fishing control; environmental sanitation; industry enrolment. Other hand, through management of fishery association conflict between household groups using bottom traps, grid-net with stake traps just got $10 \%$ compared with the previous. The number of fishing household in breeding ground was reduction; only $10 \%$ household violation compared with before establishment association. Currently, in commune no longer household who exploits extermination. The association contributed to create a stable income with high sustainability.

These are evidences to demostrate that fishery association contributed big role in fishery development and management. However, the members of association implemented well regulation in management fishery, the members outside association and community created more difficulty in management of association. This situation impacted seriously on members of the association who implemented good regulations. Need to develop specific regulations for those outside the local operators.

\section{Reference}

1. Hoa PV. (2009): Aquaculture in Thua Thien Hue Province in trade liberalization context. Hue College of economics

2. Phuoc DN. (2012): Fishery resource conservation model based on community in Tam Giang-Cau Hai lagoon, Thua Thien Hue, Vietnam. Hue University of agriculture and forestry

3. Tam NT. (2010): Evaluation fisheries co-management model on lagoon in Thua Thien Hue, Vietnam. Hue University of agriculture and forestry

4. Tuyen TV. (2008): Evaluation of co-management issues / community based coastal resource management. Hue University of agriculture and forestry

5. Tuyen TV. (2010): Property rights and rights allocation for resource co-management in Tam Giang lagoon, Vietnam. Hue University of agriculture and forestry 